\title{
Vertical habitat use of Atlantic blue marlin Makaira nigricans: interaction with pelagic longline gear
}

\author{
C. Phillip Goodyear ${ }^{1}$, Jiangang Luo ${ }^{2}$, Eric D. Prince ${ }^{3, *}$, John P. Hoolihan ${ }^{3}$, \\ Derke Snodgrass $^{3}$, Eric S. Orbesen ${ }^{3}$, Joseph E. Serafy ${ }^{3}$ \\ ${ }^{1} 1214$ North Lakeshore Drive, Niceville, Florida 32578, USA \\ ${ }^{2}$ Rosenstiel School of Marine and Atmospheric Science, University of Miami, 4600 Rickenbacker Causeway, Miami, \\ Florida 33149, USA \\ ${ }^{3}$ National Marine Fisheries Service, Southeast Fisheries Science Center, 75 VA Beach Drive, Miami, Florida 33149, USA
}

\begin{abstract}
We characterized Atlantic blue marlin Makaira nigricans temperature-depth vertical habitat utilization from data collected using 51 electronic pop-up satellite archival tags (PSATs) attached to fish released by recreational and commercial fishers. Most source data were in the form of 3 or $6 \mathrm{~h}$, temperature- and depth-frequency histograms transmitted by the tags to the ARGOS satellite system. However, high resolution time series of temperatures, depths (30 or $60 \mathrm{~s}$ resolution), and light intensity were obtained from 6 tags that were physically recovered. The distributions of times at depth were significantly different between day and night. During daylight hours, the fish were typically below the near-surface layer, often at 40 to $>100 \mathrm{~m}$, sometimes remaining below the near-surface layer at depth throughout the daylight hours, but often returning briefly to the surface. At night, the fish spent most of their time at or very close to the surface. This pattern of behavior also meant that the distributions of time at temperature were significantly different between day and night, with the fish occupying warmer strata during darkness. We evaluated the fractions of time spent by each fish within each degree of water temperature relative to the temperature of the surface mixed layer to assess assumptions used to model population abundance trends from pelagic longline catch per unit effort (CPUE) data. Frequency distributions were determined for periods of darkness, daylight and, where possible, twilight. Results were highly variable within the time series for individual fish and among individuals. Assumptions about habitat usage in previous CPUE analyses are clearly inappropriate and may lead to serious errors that can propagate through the fisheries management system.
\end{abstract}

KEY WORDS: Blue marlin · Habitat · Behavior $\cdot$ Thermocline $\cdot$ Spatial variation $\cdot$ Longlines

\section{INTRODUCTION}

The physiological adaptations of tropical pelagic fishes place fundamental constraints on the physical bounds of their habitats (Brill 1992). These otherwise invisible boundaries are shaped by each species' preferences for and/or tolerances of environmental conditions. In the open ocean, temperature and dissolved oxygen are thought to be dominant features that influence acceptable habitat (Fonteneau 1997, Eby \& Crowder 2002, Stanley \& Wilson 2004, Prince \& Goodyear 2006). Because these features vary by season and depth, the physical habitat can be viewed as an irregular, timevarying volume with physical dimensions of latitude, longitude, and depth, which are mediated by environmental preferences and physiological tolerances. Quantitative information about this habitat, and the species distribution within it, is important for both understanding the ecology of the species and its interaction with fishing gear (Brill \& Lutcavage 2001, Luo et al. 2006). This need is especially vital for species such as overfished Atlantic blue marlin Makaira nigricans, which are primarily taken as bycatch in pelagic longline fisheries directed at other species (Serafy et al. 2005). 
It is clear from observed catch patterns that hook depth influences species selectivity of longline sets (Yang \& Gong 1987, Boggs 1992, Hanamoto 1987, Nakano et al. 1997). Over the years, fishing depths have increased as tuna longline fishing fleets have shifted from targeting shallower species to the deeperdwelling bigeye tuna Thunnus obesus (Jones et al. 1998, Restrepo et al. 2003, Serafy et al. 2005). These changes have complicated estimation of population trends from catch and effort data. Understanding the ramifications of such changes is crucial to the assessment of fish stock status, because the error and uncertainties resulting from poor estimates propagate through every aspect of the fishery management process (Serafy et al. 2005, Rice et al. 2007). The amount of time marlin spend at depth may be an important factor in the evaluation and prediction of their vulnerability to pelagic longline gear (Goodyear 2003).

Hinton \& Nakano (1996) introduced a model that incorporates fish habitat information to estimate population abundance trends from longline catch-effort data by computing levels of 'effective effort' within the vertical habitat of the fish. This metric is intended to weight effort by adjusting longline effort by the proportions of time fish and hooks spend at the same depths. The proportions of time marlin spend at depth are predicted from the deviations between the temperatures at depth from the temperature of the surface mixed layer. This process, termed habitat standardization, offers a potential means to directly account for changes in fishing patterns that have occurred in the longline fishery through time (Takeuchi 2001, Yokawa \& Uozumi 2001, Yokawa et al. 2001). However, it relies entirely on detailed knowledge of gear behavior (i.e. hook depths) and marlin habitat, 2 areas of research that have recently received attention (Goodyear 2003, Serafy et al. 2005). The methodology has since been enhanced by incorporating the concept into a more formal statistical framework (Maunder et al. 2006). Bigelow \& Maunder (2007) concluded that an understanding of gear dynamics and environmental influences are important for analyzing catch per unit effort (CPUE) data correctly. The basic lack of information about actual marlin habitat use and hook depths of longline gear persists. Pop-up satellite archival tags (PSATs) are a recent technological innovation that allows fisheries independent retrieval of the temperatures and depths frequented by tagged animals. These data permit mapping habitat use in these dimensions (Luo et al. 2006). Here we present an evaluation of blue marlin vertical habitat use by temperature and depth from 51 blue marlin monitored with PSATs with particular concern for the requirements of models that predict or estimate population trends based on species distribution patterns.

\section{MATERIALS AND METHODS}

PSATs are attached to the fish externally and log the temperature, pressure (depth), and light intensity after the fish is released. Individuals can be monitored for up to several months or longer. The tags detach after a programmed interval and transmit summaries of the data through the ARGOS satellite system to a land station and then ultimately to the user via the Internet. This study used Wildlife Computers PAT model 2 and 3 tags. These tags allow the user to program pop-up date, sampling interval, criteria for premature release, bin demarcations for sampling temperature and depth, as well as transmission and memory priorities. We programmed these tags to sample depth, temperature, and light once every 30 or $60 \mathrm{~s}$. Depth and temperature records were compiled into histogram tables at $6 \mathrm{~h}$ intervals for most deployments, while a few of the early deployments summarized data at $3 \mathrm{~h}$ intervals. Temperature bins for most tags started with $\leq 12^{\circ} \mathrm{C}$, then each successive $2^{\circ} \mathrm{C}$ interval up to $32^{\circ} \mathrm{C}$, and ending with $>32^{\circ} \mathrm{C}$. Depth bins for most tags included $\leq 1 \mathrm{~m}$, followed by successive intervals of $25 \mathrm{~m}$, until reaching $250 \mathrm{~m}$, then all depths $>250 \mathrm{~m}$. Minimum and maximum temperatures and depths encountered during each binning period were also recorded. The tags used in this study were programmed for deployment durations ranging from 7 to $90 \mathrm{~d}$. A pressure-activated mechanical detachment device was used to sever the 400 pound test monofilament tether at a depth of about $1500 \mathrm{~m}$ (well before the rated $2000 \mathrm{~m}$ crush depth of the tag). This feature was intended to prevent data loss in the event of fish mortality (i.e. sinking). In addition, these tags were programed to release if the vertical movement was $\leq 5 \mathrm{~m}$ for $24 \mathrm{~h}$. This mechanism maintains data recovery for PSATs from dead marlin that did not sink below 1500 m. Release locations were estimated from global positioning systems on board the tagging vessels, while pop-up locations were estimated directly from ARGOS transmissions received from each tag. Although PSATs transmit until their batteries are exhausted, all measurements taken during the deployment are retained in the tag's nonvolatile memory. This feature allows access to the complete archived dataset should the tag be physically recovered.

All PSATs were rigged in a manner similar to those described by Block et al. (1998), Graves et al. (2002), and Prince \& Goodyear (2006). Billfish handling and tagging procedures and associated devices were as recommended by Prince et al. (2002). The tags were placed about 4 to $5 \mathrm{~cm}$ ventral to the dorsal midline, adjacent to the first several dorsal spines. An effort was made to insert the anchor through the dorsal midline, pterygiophores, and connective tissue to a depth just 
short of exiting the opposite side of the fish. We deployed 79 PSATs on blue marlin from recreational fishing and commercial longline fishing vessels during the period 2002 to 2004 (Fig. 1). Because of tag failures (i.e. non-transmitting tags) and death of 4 fish, our analyses are based on data from 51 tagged fish (Appendix 1). Of these, 6 tags were physically recovered, which allowed extraction of high-resolution archived data recorded at 30 or $60 \mathrm{~s}$ intervals during deployment.

We examined temperature and depth distribution patterns using data pooled from each fish by hours of darkness and daylight using linear methods to interpolate the data to bins of $1^{\circ} \mathrm{C}$ and $10 \mathrm{~m}$ for temperature and depth, respectively. For some analyses, we also used the high resolution data downloaded from physically recovered tags to characterize behaviors during periods of twilight. In addition to describing basic vertical habitat use patterns, we attempted to identify some aspect of blue marlin behavior that would allow prediction of blue marlin vertical habitat utilization for use in modeling population abundance trends using longline CPUE. The predominant methods currently in use are based on estimates of the proportion of time spent within successively deeper layers based on temperature relative to that of the surface mixed layer (e.g. Hinton \& Nakano 1996, Takeuchi 2001, Yokawa \& Uozumi 2001, Yokawa et al. 2001). ICCAT (2004) also recommended that CPUE simulations intended to test alternative standardization methods should adopt this approach, and that day-night fishing patterns and species distributions also be included. In order to preserve the stochastic nature of animal behavior, we partitioned observations for each fish by its daily activity patterns to be commensurate with the duration of a longline set.

For the ARGOS-transmitted data, we compiled the proportions spent within successively deeper layers of temperature relative to the temperature of the surface mixed layer (termed Delta T) by each $6 \mathrm{~h}$ period that could be clearly identified as daytime or nighttime. For each time period, there are 3 types of summarized data transmitted via ARGOS satellites: (1) the proportion of time the fish spent within 12 user-defined depth bins (i.e. $25 \mathrm{~m}$ bin resolution in this study); (2) the proportion of time the fish spent within 12 user-defined temperature bins (i.e. $2^{\circ} \mathrm{C}$ bin resolution in this study); and (3) minimum and maximum temperatures at depth minima and maxima visited by the fish, and at 6 additional depths between those points (PDT). We extracted the temperatures from the PDT data where the depth is $\leq 1 \mathrm{~m}$, and calculated the average surface temperature $\left(T_{0}\right)$ for each day. When there were no surface temperature observations (i.e. when fish did not surface for a day), we used temperatures from the

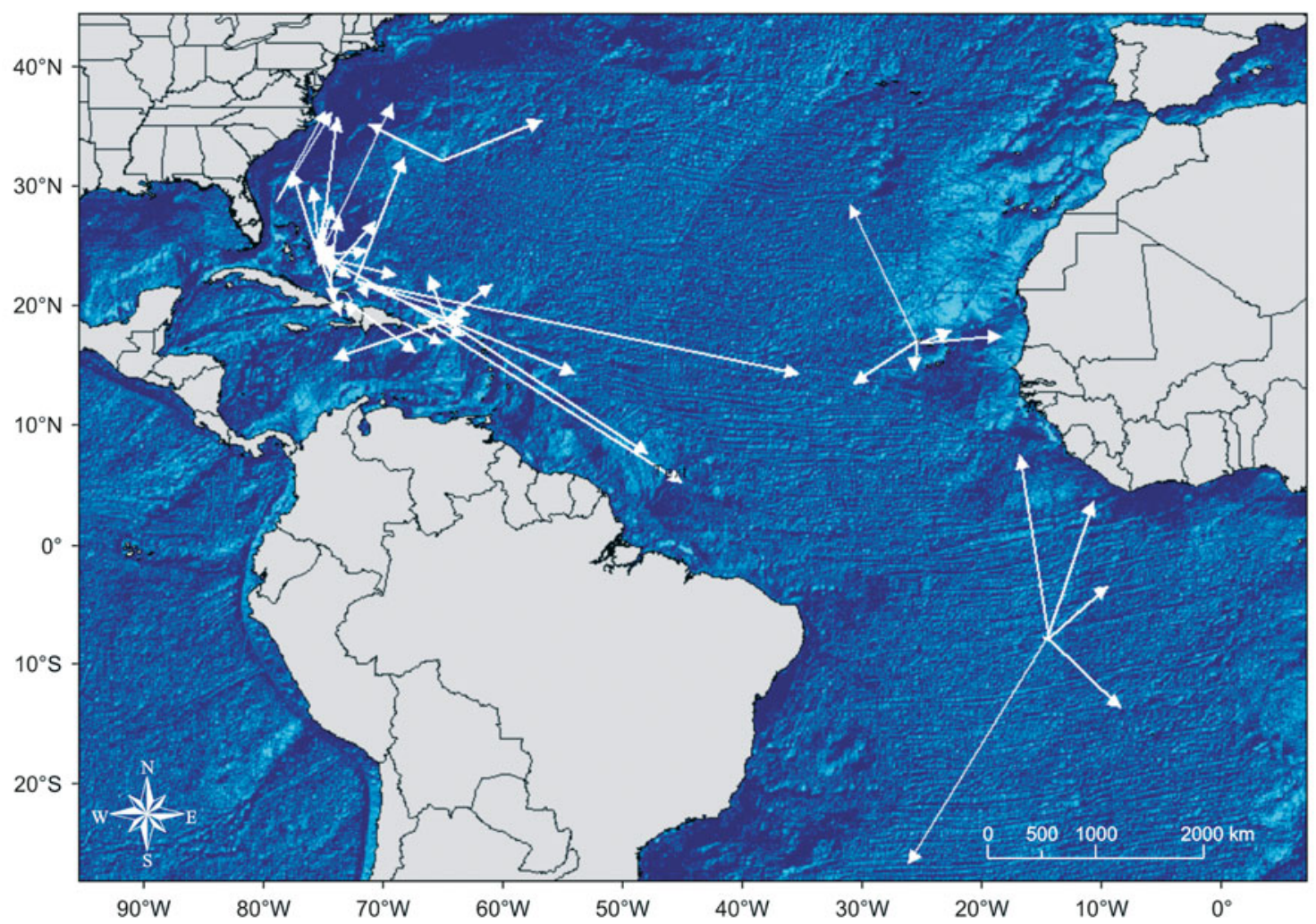

Fig. 1. Makaira nigricans. Tag release and pop-off locations of pop-up satellite archival tags (PSATs) applied to blue marlin. Arrows at the end of displacement vectors indicate pop-up locations 
previous and subsequent days to linearly interpolate the surface temperature. Temperatures are illustrated at depth when the fish is shallower using a $3 \mathrm{~d}$ running average of all measurements at depth from the tag. Next, for each depth bin we generated 360 temperatures (GMT, 6 h, 1 temperature $\mathrm{min}^{-1}$ ) from a random normal distribution, based on the range of temperatures from the PDT. Then, for each depth bin, we used the probability density function derived from the highresolution data to randomly generate the number of temperature values for each depth bin. A new temperature histogram was tabulated for the generated temperatures, and it was compared to the temperature histogram $(T)$ of the data. The differences in numbers for each temperature bin were corrected by randomly eliminating the temperature values in positive bins, and randomly adding temperature values in negative bins. Finally, Delta Ts were calculated by subtracting the generated temperatures (GT) from $T_{0}$, and the proportions of time spent at decreasing Delta $\mathrm{T}$ were tabulated at $1^{\circ} \mathrm{C}$ bin resolution.

Inspection of the high-resolution data from recovered tags revealed that most of the time spent in the surface mixed layer (Delta $\mathrm{T}$ bin $=0$ ) was actually spent at the ocean surface (arbitrarily defined here as $\leq 5 \mathrm{~m}$ ). Time spent in this stratum was treated as a separate bin. The time periods for day, night, and twilight were determined from the light level data recorded by the tag. Daylight and darkness were easily separated. The change in light level at dusk and dawn was used to bound twilight based on the midpoint of the transition in light intensity. Specifically, we quantified twilight as the $2 \mathrm{~h}$ period about dusk or dawn. Daily dawn/dusk data were pooled by day. The daily daynight-twilight patterns of time spent at the ocean surface and Delta $T$ were then determined by pooling the archived, high-resolution observations for the appropriate periods. The mean Delta $\mathrm{T}$ values were determined for each of the resulting distributions, and the
Delta T-time distributions for each day-night (and twilight) compilation were sorted by increasing depth. The data were then tabulated for several percentiles of the observed frequency distributions.

We also compiled the maximum depths and minimum temperatures explored by our tagged fish by days at large to obtain statistics related to the deepest and coldest strata used by blue marlin. This included regressions of the number of days at large when each fish included a deeper or colder stratum in its daily vertical excursions.

\section{RESULTS}

There was a significant difference in the distributions of depths occupied by our study specimens between day and night $\left(\chi^{2}=45.7 ; 25 \mathrm{df} ; \mathrm{p}<0.01\right.$; Fig. 2a). During hours of darkness the fish were higher in the water column, spending about $50 \%$ of their time in the surface $10 \mathrm{~m}$ and $86 \%$ in the upper $30 \mathrm{~m}$. In contrast, during the daytime, less than $20 \%$ of time was spent above $10 \mathrm{~m}$ and only about $46 \%$ in the upper $30 \mathrm{~m}$. In addition, the fish studied spent less than $2 \%$ of their time at or below $100 \mathrm{~m}$ at night, compared to about $17 \%$ during the day. The distribution of time at temperature was also significantly different between day and night $\left(\chi^{2}=55.1 ; 20 \mathrm{df} ; \mathrm{p}<0.01\right)$, reflecting the observed differences in the day-night depth distribution (Fig. 2b). The nighttime modal temperature was $29^{\circ} \mathrm{C}$, while the daytime mode was a degree lower at $28^{\circ} \mathrm{C}$. More interestingly, our blue marlin spent about $5 \%$ of their time within or below $25^{\circ} \mathrm{C}$ at night, increasing to $46 \%$ during the day.

We examined diel differences in the vertical behavior of blue marlin using 996 sets of nocturnal (Table 1, Fig. 3a) and 898 sets of diurnal Delta $\mathrm{T}$ distributions (Table 1, Fig. 3b). Blue marlin clearly spent more time below the surface mixed layer (Delta $\mathrm{T}=0$ ) during the
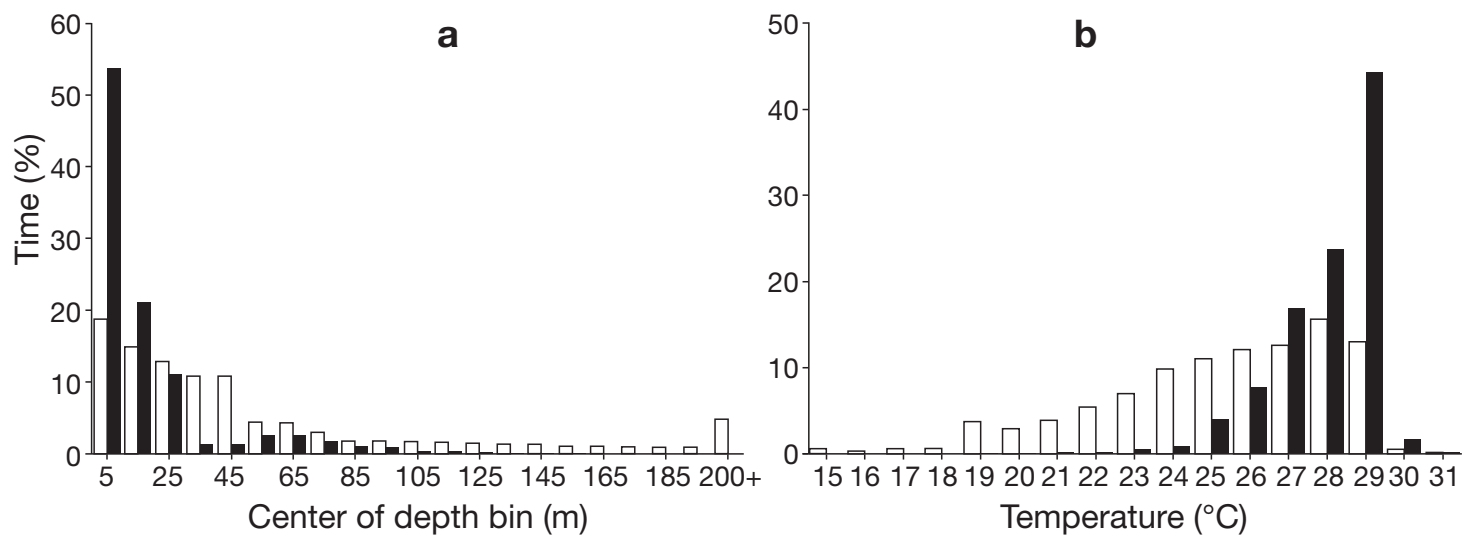

Fig. 2. Makaira nigricans. Fraction of time during daytime (white bars) and night-time (black bars) spent in (a) each successively deeper $10 \mathrm{~m}$ depth bin, and (b) each $1^{\circ} \mathrm{C}$ temperature bin, derived from PSAT data from ARGOS transmissions 
Table 1. Makaira nigricans. Fractions of time spent by blue marlin at temperature relative to the temperature of the surface mixed layer (Delta T) during hours of darkness and daylight based on ARGOS-transmitted data from PSAT tags. -: no data

\begin{tabular}{|c|c|c|c|c|c|c|c|c|c|c|c|c|}
\hline \multirow{2}{*}{ Delta $\mathrm{T}$} & & & & & \multicolumn{7}{|c|}{ Percentile of mean Delta $\mathrm{T}$} & \multirow{2}{*}{ Mean } \\
\hline & 0.010 & 0.025 & 0.050 & 0.100 & 0.250 & 0.500 & 0.750 & 0.900 & 0.950 & 0.975 & 0.990 & \\
\hline \multicolumn{13}{|c|}{ Darkness } \\
\hline 0 & 1.000 & 1.000 & 1.000 & 1.000 & 1.000 & 0.947 & 0.694 & 0.265 & 0.041 & 0.532 & 0.028 & 0.849 \\
\hline-1 & - & - & - & - & - & 0.049 & 0.251 & 0.514 & 0.473 & 0.050 & 0.338 & 0.079 \\
\hline-2 & - & - & - & - & - & 0.004 & 0.047 & 0.216 & 0.463 & 0.026 & 0.213 & 0.033 \\
\hline-3 & - & - & - & - & - & - & 0.006 & 0.006 & 0.024 & 0.064 & 0.140 & 0.018 \\
\hline-4 & - & - & - & - & - & - & 0.002 & - & - & 0.101 & 0.120 & 0.008 \\
\hline-5 & - & - & - & - & - & - & - & - & - & 0.163 & 0.079 & 0.005 \\
\hline-6 & - & - & - & - & - & - & - & - & - & 0.056 & 0.065 & 0.003 \\
\hline-7 & - & - & - & - & - & - & - & - & - & 0.006 & 0.019 & 0.002 \\
\hline-8 & - & - & - & - & - & - & - & - & - & 0.002 & - & 0.001 \\
\hline-9 & - & - & - & - & - & - & - & - & - & - & - & 0.001 \\
\hline-10 & - & - & - & - & - & - & - & - & - & - & - & 0.000 \\
\hline-11 & - & - & - & - & - & - & - & - & - & - & - & 0.000 \\
\hline-12 & - & - & - & - & - & - & - & - & - & - & - & 0.000 \\
\hline \multicolumn{13}{|l|}{ Daylight } \\
\hline 0 & 1.000 & 1.000 & 1.000 & 1.000 & 0.960 & 0.372 & 0.455 & 0.335 & 0.000 & 0.210 & 0.017 & 0.583 \\
\hline-1 & - & - & - & - & 0.024 & 0.516 & 0.075 & 0.132 & 0.000 & 0.201 & 0.005 & 0.144 \\
\hline-2 & - & - & - & - & 0.016 & 0.098 & 0.025 & 0.018 & 0.000 & 0.016 & 0.001 & 0.069 \\
\hline-3 & - & - & - & - & - & 0.015 & 0.030 & 0.042 & 0.049 & 0.004 & 0.000 & 0.043 \\
\hline-4 & - & - & - & - & - & - & 0.154 & 0.043 & 0.368 & 0.028 & 0.005 & 0.031 \\
\hline-5 & - & - & - & - & - & - & 0.151 & 0.037 & 0.301 & 0.013 & 0.032 & 0.026 \\
\hline-6 & - & - & - & - & - & - & 0.041 & 0.031 & 0.184 & 0.016 & 0.114 & 0.022 \\
\hline-7 & - & - & - & - & - & - & 0.044 & 0.021 & 0.041 & 0.012 & 0.202 & 0.022 \\
\hline-8 & - & - & - & - & - & - & 0.021 & 0.046 & 0.000 & 0.028 & 0.214 & 0.019 \\
\hline-9 & - & - & - & - & - & - & 0.004 & 0.071 & 0.000 & 0.025 & 0.398 & 0.020 \\
\hline-10 & - & - & - & - & - & - & - & 0.170 & 0.003 & 0.223 & 0.013 & 0.012 \\
\hline-11 & - & - & - & - & - & - & - & 0.053 & 0.008 & 0.031 & - & 0.003 \\
\hline-12 & - & - & - & - & - & - & - & 0.002 & 0.027 & 0.087 & - & 0.003 \\
\hline-13 & - & - & - & - & - & - & - & - & 0.010 & 0.101 & - & 0.001 \\
\hline-14 & - & - & - & - & - & - & - & - & 0.007 & 0.006 & - & 0.001 \\
\hline-15 & - & - & - & - & - & - & - & - & 0.001 & - & - & 0.000 \\
\hline
\end{tabular}

daytime than in darkness. Overall, $85 \%$ of their nighttime hours and $58 \%$ of their daytime hours were spent within the surface mixed layer (Table 1). However, inspection of these data revealed high variability in the individual distributions. For example, the percentage of time at depths occupied by the Delta $\mathrm{T}$ distribution with median mean depths indicated about $95 \%$ of time was spent in the surface mixed layer at night compared to only $37 \%$ during the day. The high-resolution data from recovered tags yielded 404 daily estimates of time spent at Delta $\mathrm{T}$ for conditions of nighttime and twilight, and 403 daily estimates for daytime conditions (Fig. 3c-e). These data indicated a trend of increasing use of cooler layers during the daytime, compared to night, with an intermediate behavior during periods of twilight. These results are entirely consistent with our analyses of the ARGOS summary datasets that were only available in the bins compiled by the tags' onboard software prior to transmission.

The detailed archival data from recovered PSATs provide a complete uninterrupted history of temperature, depth, and light levels experienced by blue mar- lin during the entire length of monitoring, from initial release through first transmission to the ARGOS satellite system. Inspection of the depths explored (Fig. 4) revealed that characterization of habitat in terms of proportions of time spent at depth and temperature is inadequate to describe how these fish actually use the available water column. Fig. 4 was constructed with data retrieved from a single recovered tag. Each panel represents the activity pattern during a single day of different weeks over a $39 \mathrm{~d}$ monitoring period. Fig. $4 \mathrm{a}$, b shows the daily activity pattern of early- and mid-time series. A decidedly surface orientation at night and deeper use of the water column during the daytime, including the deepest observed dive to $340 \mathrm{~m}$ (Fig. 4a). During this period, the fish spent considerable time below the surface mixed layer during daylight hours. After descending at the beginning of the day, this individual remained deep in the water column without returning to the surface until late in the day (Fig. 4a). The time trace depicted in Fig. 4b is $1 \mathrm{wk}$ later, when the fish was wandering more widely in the water column with frequent returns to the surface. 


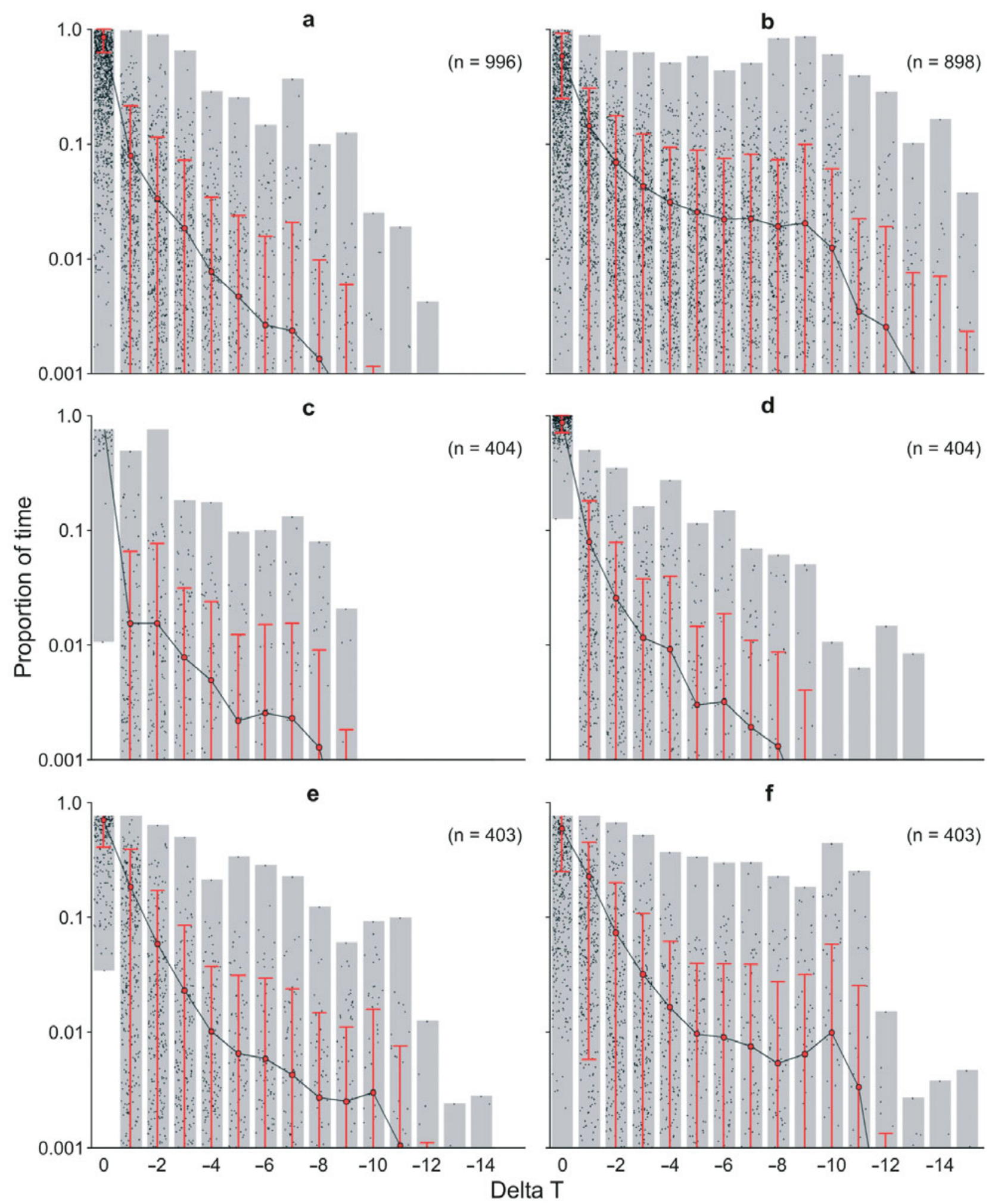

Fig. 3. Makaira nigricans. Proportions of time spent by Delta T (temperature of the surface mixed layer) (a) during hours of darkness estimated from the ARGOS data, (b) during daytime hours estimated from the ARGOS data, (c) during hours of darkness estimated from archived data, (d) during twilight hours estimated from archived data, (e) during daytime hours estimated from archived data, and (f) during daytime hours estimated from archived data, but excluding time spent at the surface. Shaded bars signify the range of observations (depicted by small gray dots). Red circles and associated error bars denote means and $95 \%$ confidence intervals 


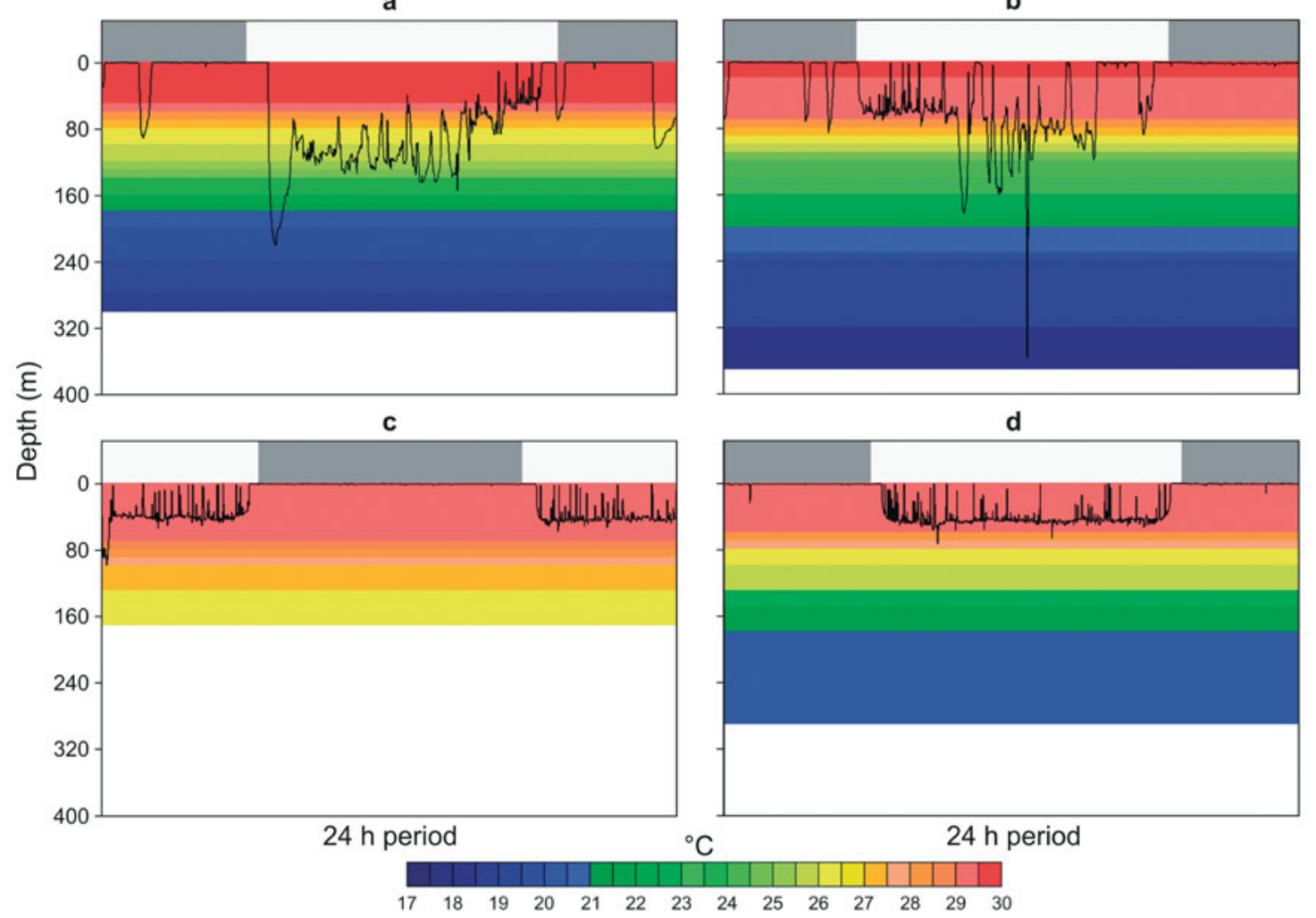

Fig. 4. Makaira nigricans. Excerpt from a time series (12 October to 20 November 2003) of temperature and depth measurements by PSAT 27825 applied to a blue marlin and later recovered. The shaded/white area above the 0 depth value on the $y$-axis denotes darkness/daylight periods, respectively. Excerpts were taken from (a) the first part of the time series on 17 October, showing typical daytime diving activity during the first part of the track, (b) the early part of the time series on 24 October, showing the deepest dive $(340 \mathrm{~m})$ during the track, (c) the latter part of the time series on 17 November, showing quiescent (dormant) activity during nocturnal periods towards the end of the track, and (d) near the end of the time series on 19 November, showing restrictive daytime diving activity during the later part of the track

Later in the time series, this marlin became much more surface oriented, but still showed clear day-night shifts in depths occupied (Fig. 4c,d). Nighttime depths were mostly restricted to the very near surface layer, and daytime depths were almost entirely restricted to the surface mixed layer, with only infrequent exploration of deeper, cooler water (Fig. 4c,d). The timedepth habitat use by another monitored individual trended in the opposite direction from initially shallow to later deeper habitat occupancy.

Results also illustrate that a disproportionate fraction of the time spent in the surface mixed layer was at the surface itself, particularly at night. Hooks on pelagic longlines are generally at the surface for only very brief periods during set and retrieval operations. Consequently, this region should receive special treatment. We partitioned the frequency distributions of time into the proportion of time in the surface $5 \mathrm{~m}$ and the remainder into proportions at Delta $\mathrm{T}$ (Table 2). The proportions of time at the surface varied by time of day, with means of $91 \%$ during the night, $52 \%$ during twilight, and $22 \%$ during the daytime (Table 2).
Remarkably, the percentage of time at depth occupied by the Delta $\mathrm{T}$ distribution with median mean depths indicates that nearly all (>99\%) of the time spent in the surface mixed layer at night was at the surface (Table 2). In contrast, about half of the time during twilight was at the surface and a much smaller proportion during the day (Table 2). Excluding the time at the surface from the computation of times at Delta $\mathrm{T}$ for the detailed data shifts the proportions at higher Delta $\mathrm{T}$ upward (cf. Fig. 3e,f).

In order to assess the effect of the deepest recorded dives on vertical habitat use, we examined maximum depths and minimum temperatures explored by our tagged fish by days at large and time of day (Figs. 5 \& 6). Marlin occupied deeper strata (maximum observed depth, $\left.D_{\max }\right)$ in their daily movements with increasing days at large, $T\left(D_{\max }=116.3 T^{0.266} ; \mathrm{r}^{2}=0.262 ; F=76.5\right.$; $\mathrm{p}<0.001 ; 216 \mathrm{df})$, but the overall pattern reflects high daily variability (Fig. 5). A few of the monitored fish confined their vertical excursions to less than $100 \mathrm{~m}$ during the time monitored, while another ventured below $800 \mathrm{~m}$, for an average maximum depth of $319 \mathrm{~m}$ 
Table 2. Makaira nigricans. Fractions of time spent by blue marlin in the upper $5 \mathrm{~m}$ and at temperature relative to the temperature of the surface mixed layer (Delta T) during hours of darkness, twilight and daylight based on data retrieved from recovered PSAT tags. -: no data

\begin{tabular}{|c|c|c|c|c|c|c|c|c|c|c|c|c|}
\hline \multirow{2}{*}{$\begin{array}{l}\text { Depth or } \\
\text { Delta T }\end{array}$} & \multirow[b]{2}{*}{0.010} & \multirow[b]{2}{*}{0.025} & \multirow[b]{2}{*}{0.050} & \multirow[b]{2}{*}{0.100} & \multicolumn{3}{|c|}{ Percentile of mean Delta $T$} & \multirow[b]{2}{*}{0.900} & \multirow[b]{2}{*}{0.950} & \multirow[b]{2}{*}{0.975} & \multirow[b]{2}{*}{0.990} & \multirow{2}{*}{ Mean } \\
\hline & & & & & 0.250 & 0.500 & 0.750 & & & & & \\
\hline \multicolumn{13}{|l|}{ Darkness } \\
\hline$>5 \mathrm{~m}$ & 1.000 & 1.000 & 1.000 & 1.000 & 0.998 & 0.991 & 0.914 & 0.358 & 0.525 & 0.641 & 0.584 & 0.911 \\
\hline 0 & - & - & - & - & 0.002 & 0.003 & 0.045 & 0.362 & 0.053 & 0.038 & 0.070 & 0.037 \\
\hline-1 & - & - & - & - & - & 0.006 & 0.024 & 0.241 & 0.082 & 0.029 & 0.020 & 0.015 \\
\hline-2 & - & - & - & - & - & 0.001 & 0.016 & 0.038 & 0.148 & 0.022 & 0.021 & 0.015 \\
\hline-3 & - & - & - & - & - & - & 0.001 & 0.001 & 0.141 & 0.025 & 0.029 & 0.008 \\
\hline-4 & - & - & - & - & - & - & - & - & 0.029 & 0.042 & 0.043 & 0.005 \\
\hline-5 & - & - & - & - & - & - & - & - & 0.022 & 0.031 & 0.041 & 0.002 \\
\hline-6 & - & - & - & - & - & - & - & - & - & 0.067 & 0.044 & 0.003 \\
\hline-7 & - & - & - & - & - & - & - & - & - & 0.076 & 0.068 & 0.002 \\
\hline-8 & - & - & - & - & - & - & - & - & - & 0.029 & 0.079 & 0.001 \\
\hline \multicolumn{13}{|l|}{ Twilight } \\
\hline$>5 \mathrm{~m}$ & 1.000 & 0.958 & 0.898 & 0.710 & 0.552 & 0.446 & 0.339 & 0.674 & 0.523 & 0.456 & 0.581 & 0.520 \\
\hline 0 & - & 0.042 & 0.065 & 0.290 & 0.423 & 0.477 & 0.423 & 0.013 & 0.119 & 0.174 & 0.023 & 0.344 \\
\hline-1 & - & - & 0.020 & - & 0.004 & 0.073 & 0.238 & 0.044 & 0.179 & 0.066 & 0.017 & 0.079 \\
\hline-2 & - & - & 0.016 & - & 0.004 & 0.004 & - & 0.074 & 0.013 & 0.004 & 0.019 & 0.026 \\
\hline-3 & - & - & - & - & 0.004 & - & - & 0.111 & 0.019 & 0.100 & 0.025 & 0.012 \\
\hline-4 & - & - & - & - & 0.004 & - & - & 0.084 & 0.038 & 0.021 & 0.081 & 0.009 \\
\hline-5 & - & - & - & - & 0.008 & - & - & - & 0.040 & 0.042 & 0.058 & 0.003 \\
\hline-6 & - & - & - & - & - & - & - & - & 0.071 & 0.112 & 0.113 & 0.003 \\
\hline-7 & - & - & - & - & - & - & - & - & - & 0.025 & 0.029 & 0.002 \\
\hline-8 & - & - & - & - & - & - & - & - & - & - & 0.054 & 0.001 \\
\hline \multicolumn{13}{|l|}{ Daylight } \\
\hline$>5 \mathrm{~m}$ & 0.998 & 0.990 & 0.979 & 0.741 & 0.022 & 0.134 & 0.501 & 0.176 & 0.263 & 0.029 & 0.051 & 0.222 \\
\hline 0 & 0.002 & 0.010 & 0.008 & 0.172 & 0.977 & 0.562 & 0.053 & 0.617 & 0.394 & 0.054 & 0.102 & 0.478 \\
\hline-1 & - & - & 0.007 & 0.072 & 0.002 & 0.245 & 0.033 & 0.012 & 0.015 & 0.051 & 0.021 & 0.183 \\
\hline-2 & - & - & 0.006 & 0.012 & 0.000 & 0.049 & 0.170 & 0.011 & 0.015 & 0.227 & 0.052 & 0.058 \\
\hline-3 & - & - & - & 0.003 & 0.000 & 0.011 & 0.159 & 0.016 & 0.030 & 0.495 & 0.226 & 0.023 \\
\hline-4 & - & - & - & - & - & - & 0.078 & 0.016 & 0.029 & 0.145 & 0.127 & 0.010 \\
\hline-5 & - & - & - & - & - & - & 0.005 & 0.015 & 0.041 & - & 0.134 & 0.007 \\
\hline-6 & - & - & - & - & - & - & - & 0.019 & 0.082 & - & 0.280 & 0.006 \\
\hline-7 & - & - & - & - & - & - & - & 0.015 & 0.091 & - & 0.007 & 0.004 \\
\hline-8 & - & - & - & - & - & - & - & 0.014 & 0.006 & - & - & 0.003 \\
\hline-9 & - & - & - & - & - & - & - & 0.029 & 0.018 & - & - & 0.003 \\
\hline-10 & - & - & - & - & - & - & - & 0.023 & 0.010 & - & - & 0.003 \\
\hline-11 & - & - & - & - & - & - & - & 0.027 & 0.005 & - & - & 0.001 \\
\hline-12 & - & - & - & - & - & - & - & 0.012 & 0.000 & - & - & 0.000 \\
\hline-13 & - & - & - & - & - & - & - & - & 0.001 & - & - & 0.000 \\
\hline-14 & - & - & - & - & - & - & - & - & 0.001 & - & - & 0.000 \\
\hline
\end{tabular}

(Fig. 6). There was also a significant trend for our marlin to have visited cooler strata (minimum observed temperature, $C_{\min }$ ) in their daily movements with increasing days at large $\left(C_{\min }=24.5 T^{-0.103} ; \mathrm{r}^{2}=0.421\right.$; $F=157.0 ; 217 \mathrm{df}$ ) but the overall pattern also reflects high daily variability (Fig. 6). The mean of the lowest temperatures explored was $17^{\circ} \mathrm{C}$, with a range of just less than $10^{\circ} \mathrm{C}$ to just over $24^{\circ} \mathrm{C}$.

\section{DISCUSSION}

Overall, our observations indicate substantial variability in habitat use by temperature and depth, and in terms of time spent at temperature relative to the surface mixed layer. This variability occurred within and among individual blue marlin. The Delta $\mathrm{T}$ fractions for the different percentiles in Tables $1 \& 2$ highlight the stochastic nature of the behavior with respect to Delta $\mathrm{T}$. The distributions are not only highly variable, but even when sorted by mean Delta $\mathrm{T}$, there is no smooth progression of increasing use of cooler Delta $\mathrm{T}$ with the increase in the mean. For example, the fish contributing to observations at the 90th and 95th percentiles of the distributions (sorted by mean) ventured into relatively colder/deeper water than those at the 97.5th and 99th percentiles. These observations support the view that the behavior of blue marlin with respect to depth is more complex than can be captured by a model of Delta $\mathrm{T}$ alone.

We suspect that time spent at the surface may not be primarily associated with feeding behavior, but takes place when the fish are in a quiescent mode, particularly during nocturnal periods. Blue marlin appear to 


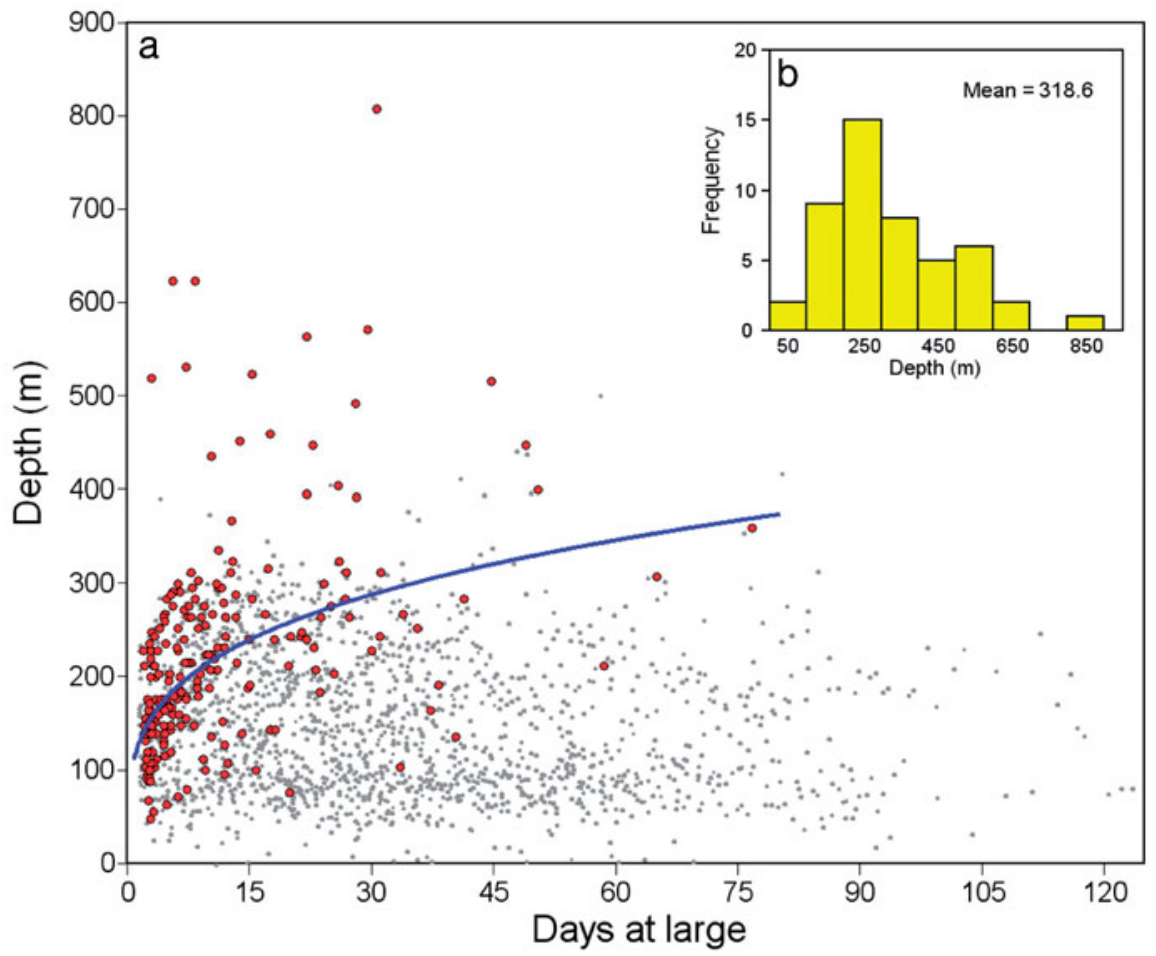

Fig. 5. Makaira nigricans. Maximum depths to which each tagged fish dove during its time at large. (a) Deepest dive in each $6 \mathrm{~h}$ record. Larger red dots signify first records of each fish at the observed depth, and the blue line is the exponential fit to the first occurrence data. (b) Deepest dives observed for each fish

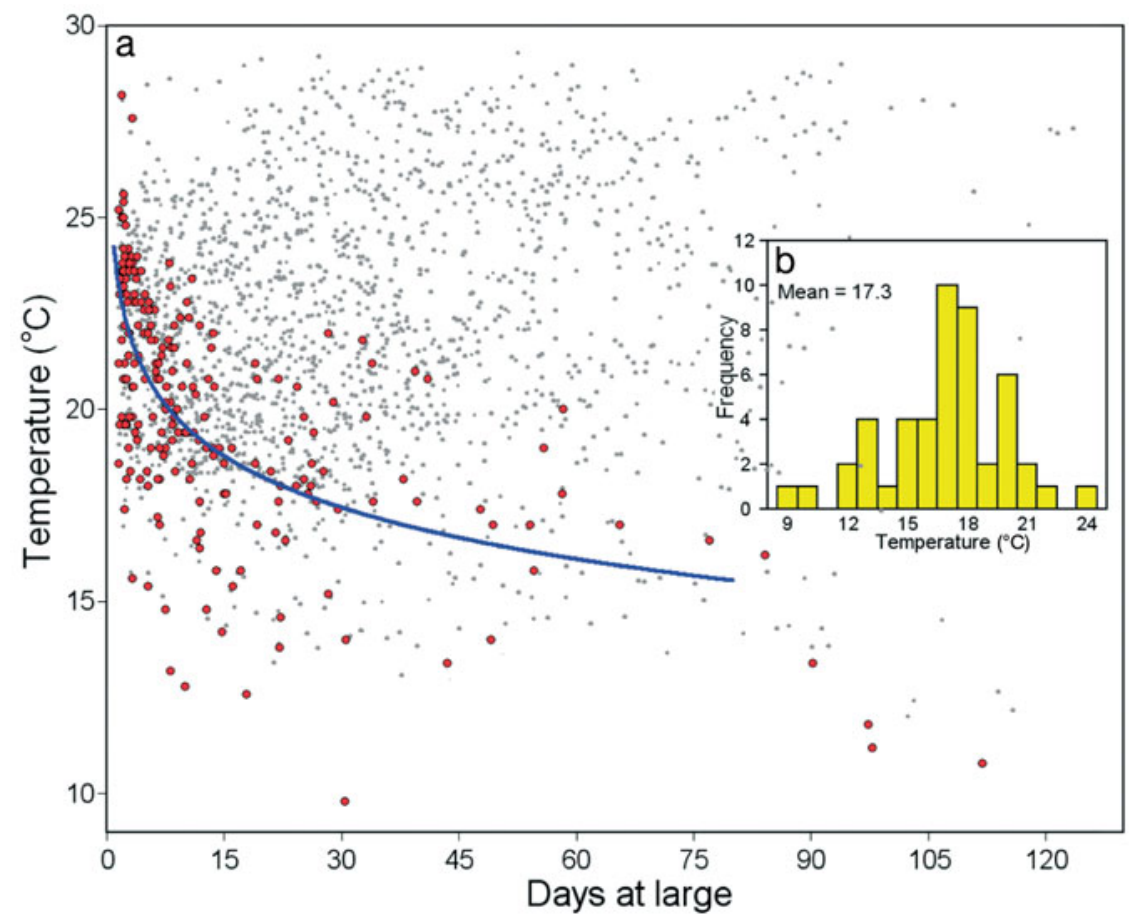

Fig. 6. Makaira nigricans. Minimum temperatures experienced by each tagged fish during its time at large. (a) Coolest temperature for each fish in each $6 \mathrm{~h}$ record. Larger red dots signify first records of each fish at the observed temperature, and the blue line is the exponential fit to the first occurrence data. (b) Coolest temperature observed for each fish be daylight sight feeders that regularly penetrate into the water column to feed or possibly view prey above. The temperatures and depths explored are likely a function of the distribution of the forage species (Dagorn et al. 2000) more so than a response to the Delta $T$ experienced by the marlin. Furthermore, the forage depth distribution reflects its species composition and relationship to oceanographic features, such as the thermocline, which probably represents a physiological 'boundary' for many forage species (from both directions). There is a strong association between Delta $\mathrm{T}$ and the temperature distribution within and above the thermocline. These factors would lead to strong, spatially local correlations between Delta $\mathrm{T}$ and habitat use that are unlikely to be highly predictive across the entire vertical spatial distribution of blue marlin. Certainly, the individual fish depicted in Fig. 4 exhibited fundamentally different behaviors during the period monitored.

Our blue marlin often made deep, short-duration dives that took them into relatively cold environments (Fig. 5). The mode was at 200 to $300 \mathrm{~m}$, but a dive below $800 \mathrm{~m}$ was observed. These correspond to a mode of minimum temperatures ranging from 17 to $18^{\circ} \mathrm{C}$, and a minimum observed temperature below $10^{\circ} \mathrm{C}$ (Fig. 6). Clearly, blue marlin can penetrate these depths and temperatures as conditions require, if only briefly. Such excursions may be related to feeding or predator avoidance and are no doubt facilitated by a brain heater organ that permits ocular and physical function at low temperatures and low light conditions (Block 1986, Block \& Finnerty 1994, Fritsches et al. 2003, 2005). In any event, the view that this species' vertical habitat does not extend to depths targeted by deep-set pelagic longlines (i.e. $>200 \mathrm{~m}$ ) is false. Previous studies of blue marlin monitored via acoustic telemetry (Block et al. 1992a,b) were conducted over much shorter time periods (hours to days) than reported here (weeks and months). Resulting 
depth and temperature preferences from those studies predictably indicated a more limited use of the water column. We predict that even deeper and colder excursions will be revealed as longer and longer tag deployments become technologically possible.

From our results, we feel the mean behaviors over all Delta $\mathrm{T}$ are not locally predictive for either an individual animal or its spatial location. Fishers tend to set gear in proximity to local oceanographic features, such as current rips or temperature boundaries (Hoey \& Moore 1999, Watson et al. 2005). Consequently, the observed mean behavior with respect to Delta T may bear little relation to actual behavior patterns where longlines are commonly deployed. Similarly, oceanographic features at set locations probably deviate importantly from mean oceanographic conditions in the $5^{\circ} \times 5^{\circ}$ latitude-longitude cells used to associate longline sets with physical measures of their habitat (Goodyear 2003). Further, longline sets tend to span day-night boundaries, and consequently the proportions in each must vary with latitude and season. The strong day-night differences in species distributions within habitat documented herein suggest that CPUE analyses to estimate population abundance trends based on habitat assumptions must integrate day-night behaviors. These factors include longline effort and the depth-, temperature-, and/or Delta T-predictors of vertical habitat space. Depending on the availability of detailed effort data, this task may or may not be feasible for the analysis of historical CPUE trends using habitat-based methods, regardless of whether the species distributions estimated here are appropriate.

For reasons of economy, our study focused on areas where blue marlin were highly available to recreational and longline fishers. The blue marlin included in this study were selected based on the availability of platforms to perform the tagging operations, and may not be representative (random) of animal behavior within the Atlantic-wide population. Our current temperature utilization data are similar to the findings of Goodyear (2003), who contrasted World Ocean Atlas predictions of average sea surface temperatures (Conkright et al. 1998) with longline sets that caught blue marlin. However, Goodyear (2003) found that the highest proportion of positive sets occurred where average surface temperatures were $27^{\circ} \mathrm{C}$, about $1{ }^{\circ} \mathrm{C}$ below the peak daytime temperature observed in the present study. Also, the lower (cooler) tail of the distribution estimated by Goodyear (2003) included temperatures not observed in the present study. Part of the difference between the 2 findings is likely the result of Goodyear's application of monthly averages, which do not reflect micro-scale features of ocean circulation. However, it is also likely that our data concerning tem- peratures and depths used by blue marlin are biased to some extent by the local adaptation of the fish we tagged. Therefore, it seems likely that blue marlin nearer to the northern/southern limits of their range may have temperature and depth habitat profiles that differ importantly from those seen in our study.

Absolute temperature, Delta T, actual depth (light concentration), and prey and predator distributions and abundances are all likely to be important features of blue marlin habitat. Our data support the notion that blue marlin vertical habitat is a complex multivariable continuum consisting of a near-surface 'core' area where they spend most of their time, particularly at night, and an elastic temperature-depth space defined by physiological tolerances and predator-prey distributions. The mixed surface layer is also the warmest part of the local habitat, which may have some metabolic significance (Brill 1996). All of our fish periodically descended into cooler water below the surface, typically during daylight hours. We believe most of this activity was associated with feeding behavior, possibly to exploit resources near, within, or below the thermocline, or to provide a better view of potential prey above. However, our fish sometimes remained at depth for the entire day, possibly suggesting successful foraging at depth, a view further supported by diet observations (Goodyear et al. 2003). For example, deep water prey items such as the mesopelagic snake mackerels, Gempylidae, or pomfrets Brama spp. have occasionally been identified in the diet of blue marlin (Erdman 1962, Baker 1966, Strasburg 1970, Rivas 1975, Brock 1984, Harvey 1989). Although some deep water prey undertake diurnal vertical migrations at night, marlin appear to be primarily daytime sight feeders. We found that the same fish would make frequent trips to the surface during the daylight hours. We speculate that this change of behaviors may be associated with differing spatial distributions of prey species, and that blue marlin can make use of a larger vertical habitat than that actually frequented on most days.

For whatever reasons, our fish explored depths to more than $800 \mathrm{~m}$ and encountered absolute temperatures of less than $10^{\circ} \mathrm{C}$ and Delta Ts of $-15^{\circ} \mathrm{C}$. Certainly, their physiological and anatomical adaptations permit short-term excursions into otherwise inhospitable temperatures and low light conditions in response to visual and olfactory cues. This may actually enhance predation success of less adapted prey species downward through the thermocline. These colder deeper strata may be disproportionately important components of blue marlin habitat, particularly in regions where dissolved oxygen does not limit the depth of acceptable habitat, as reported for the western North Atlantic Ocean (Prince \& Goodyear 2006). 
Our PSAT analysis presents the most comprehensive description to date of actual vertical habitat use for Atlantic blue marlin, as it relates to water temperature and depth. Vertical movements extending from the surface to greater than $800 \mathrm{~m}$ are reflected in the wide spectrum of food items consumed by blue marlin (Rivas 1975). The size range of organisms eaten by adults is relatively large, ranging from $2 \mathrm{~cm}$ sargassumfish Histrio histrio (E. D. Prince pers. obs.) to $20 \mathrm{~kg}$ white marlin Tetrapturus albidus (D. Snodgrass pers. obs.) and $29 \mathrm{~kg}$ bigeye tuna (Strasburg 1969). As such, our results offer invaluable information relevant to ecosystem-based management, an increasingly mandated approach to conserve fisheries (Kitchell et al. 2006). Specifically, this information may contribute to improving modeling approaches that address vulnerability and encounter probabilities of blue marlin with pelagic longline fishing gears.

In the context of habitat standardizations of abundance trends from CPUE data, several issues need additional study. The day-night timing of gear deployment and retrieval varies with target species, and it is likely that the diel pattern of gear depth distributions and fish feeding behavior would translate to important differences in blue marlin vulnerability to different fishing practices. Having said this, there appear to be few places in the vertical tropical pelagic environment in which longline gear deployments can avoid interactions with blue marlin. In addition, the physical composition of fishing equipment has changed with time and target species, such that the historical trends in fished times at depth are uncertain at best. Boggs (1992) observed that striped marlin Tetrapturus audax had a much greater propensity to take longline baits that were moving during deployment or retrieval rather than while settled. Such observations indicate that, by itself, hook time at depth is a crude index of vulnerability; fish can likely perceive a given bait from olfactory and visual cues from 10 s if not 100s of meters away and home in on it within seconds. Life of an apex predator in the patchy food-poor environment of the open ocean must depend on more than random encounters. To this end, as new versions of PSAT technology advance to a wider selection of environmental sensors, increased memory, greater battery life, and improved anchoring mechanisms, our understanding of vertical habitat use of this species can be expected to improve.

Acknowledgements. The Billfish Foundation and US National Marine Fisheries Service supported C.P.G.'s contribution to this study. R. Nelson, B. Luckhurst, and G. Harvey assisted in deploying PSATs. We thank all participants in our Adopt-ABillfish Program for sponsoring tags, providing tagging platforms, and transferring fish to our tagging vessels. References to commercial products do not imply endorsement by the National Marine Fisheries Service or the authors.

\section{LITERATURE CITED}

Baker AN (1966) Food of marlins from New Zealand waters. Copeia 1966:818-822

Bigelow KA, Maunder MN (2007) Does habitat or depth influence catch rates of pelagic species? Can J Fish Aquat Sci 64: 1581-1594

Block BA (1986) Structure of the brain and eye heater tissue in marlins, sailfish, and spearfish. J Morphol 190:169-189

Block BA, Finnerty JR (1994) Endothermy in fishes: a phylogenetic analysis of constraints, predispositions and selection pressures. Environ Biol Fishes 40:283-302

Block B, Booth D, Carey F (1992a) Depth and temperature of blue marlin, Makaira nigricans, observed by acoustic telemetry. Mar Biol 114:175-183

Block B, Booth D, Carey F (1992b) Direct measurement of swimming speeds and depth of blue marlin. J Exp Biol 166: 267-284

- Block BA, Dewar H, Farwell C, Prince ED (1998) A new satellite technology for tracking the movements of Atlantic bluefin tuna. Proc Natl Acad Sci USA 95:9384-9389

Boggs CH (1992) Depth, capture time, and hooked longevity of longline-caught pelagic fish: timing bites of fish with chips. Fish Bull 90:642-658

Brill RW (1996) Selective advantages conferred by the high performance physiology of tunas, billfishes, and dolphin fish. Comp Biochem Physiol 113:3-15

Brill RW, Lutcavage ME (2001) Understanding environmental influences on movements and depth distributions of tunas and billfishes can significantly improve population assessments. Am Fish Soc Symp 25:179-198

Brock RE (1984) A contribution to the trophic biology of the blue marlin (Makaira nigricans Lacepede, 1802) in Hawaii. Pac Sci 38:141-149

Conkright M, Levitus S, O'Brien T, Boyer T, Antonov J, Stephens C (1998) World ocean atlas 1998 CD-ROM data set documentation. Tech Rep 15, NODC Internal Report, Silver Spring, MD

> Dagorn L, Bach P, Jossé E (2000) Movement patterns of large bigeye tuna (Thunnus obesus) in the open ocean determined using ultrasonic telemetry. Mar Biol 136:361-371

Eby LA, Crowder LB (2002) Hypoxia-based habitat compression in the Neuse River Estuary: context-dependent shifts in behavioral avoidance thresholds. Can J Fish Aquat Sci 59: 952-965

Erdman DS (1962) The sport fishery for blue marlin off Puerto Rico. Trans Am Fish Soc 97:131-137

Fonteneau A (1997) Atlas of tropical tuna fisheries: world catches and environment. Orstrom Editions, Paris

> Fritsches KA, Marshall NJ, Warrant EJ (2003) Retinal specializations in the blue marlin: eyes designed for sensitivity to low light levels. Mar Freshw Res 54:333-341

Fritsches KA, Brill RW, Warrant EJ (2005) Warm eyes provide superior vision in swordfishes. Curr Biol 15:55-58

Goodyear CP (2003) Tests of the robustness of habitatstandardized abundance indices using simulated blue marlin catch-effort data. Mar Freshw Res 54:369-382

Goodyear CP, Die D, Kerstetter DW, Olson DB, Prince E, Scott GP (2003) Habitat standardization of CPUE indices: research needs. Collect Vol Sci Pap ICCAT 55:613-623

Graves JE, Luckhurst BE, Prince ED (2002) An evaluation of pop-up satellite tags for estimating postrelease survival of blue marlin (Makaira nigricans) from a recreational fishery. Fish Bull 100:134-142

Hanamoto E (1987) Effect of oceanographic environment on bigeye tuna distribution. Bull Jpn Soc Fish Oceanogr 51: 203-216

Harvey GCM (1989) An historical review of recreational and 
artisanal fisheries for billfish in Jamaica, 1976-1988. Collect Vol Sci Pap ICCAT 30:440-450

Hinton MG, Nakano H (1996) Standardizing catch and effort statistics using physiological, ecological, or behavioral constraints and environmental data, with an application to blue marlin (Makaira nigricans) catch and effort data from the Japanese longline fisheries in the Pacific. Bull IATTC 21: $171-200$

Hoey JJ, Moore N (1999) Captain's report. Multi-species characteristics for the U.S. Atlantic pelagic longline fishery. Natl Fish Inst Rep to NOAA, National Marine Fisheries Service, Silver Spring, MD. Available at: www.sefsc.noaa.gov/ seaturtlecontractreports.jsp

ICCAT (2004) Report of the 2003 meeting of the ICCAT Working Group on Assessment Methods. Collect Vol Sci Pap ICCAT 56:75-105

Jones C, Prince ED, Scott GP, Farber MI (1998) Models of blue marlin and white marlin in the Atlantic Ocean: a case history. In: Funk F, Quinn TJ II, Heifetz J, Ianelli JN and others (eds) Fishery stock assessment models. Lowell Wakefield Fish Symp, Univ Alaska Sea Grant Coll Prog Rep 98-01: 99-119

Kitchell JF, Martell SJD, Walters CJ, Jensen OP and others (2006) Billfishes in an ecosystem context. Bull Mar Sci 79:669-682

Luo J, Prince ED, Goodyear CP, Luckhurst BE, Serafy JE (2006) Vertical habitat utilization by large pelagic animals: a quantitative framework and numerical method for use with popup satellite tag data. Fish Oceanogr 15:208-229

Maunder MN, Hinton MG, Bigelow KA, Langley AD (2006) Developing indices of abundance using habitat data in a statistical framework. Bull Mar Sci 79:545-559

Nakano H, Okazaki M, Okamoto H (1997) Analysis of catch depth by species for tuna longline fishery based on catch by branch lines. Bull Natl Res Inst Far Seas Fish 34:43-62

Prince ED, Goodyear CP (2006) Hypoxia based habitat compression of tropical pelagic fishes. Fish Oceanogr 15:451-464

Prince ED, Ortiz M, Venizelos A, Rosenthal DS (2002) In-water conventional tagging techniques developed by the Cooperative Tagging Center for large, highly migratory species. Am Fish Soc Symp 30:155-171
Restrepo V, Prince ED, Scott GP, Uozumi Y (2003) ICCAT stock assessments of Atlantic billfish. Mar Freshw Res 54:361-367

Rice PH, Goodyear CP, Prince ED, Snodgrass D, Orbesen ES, Serafy JE (2007) Use of catenary geometry to estimate hook depth during near-surface pelagic longline fishing: theory versus practice. N Am J Fish Manag 27:1148-1161

Rivas LR (1975) Synopsis of biological data on blue marlin, Makaira nigricans Lacepede, 1802. In: Shomura RS, Williams F (eds) Proc Int Billfish Symp Kailua-Kona, HI, 9-12 August 1972. Part 3, Species Synopses NOAA Tech Rep NMFS SSRF-675:1-16

Serafy JE, Diaz GA, Prince ED, Orbesen ES, Legault CM (2005) Atlantic blue marlin, Makaira nigricans, and white marlin, Tetrapterus albidus, bycatch of the Japanese pelagic longline fishery, 1960-2000. Mar Fish Rev 66:9-20

Stanley DR, Wilson CA (2004) Effect of hypoxia on the distribution of fishes associated with a petroleum platform off coastal Louisiana. N Am J Fish Manag 24:662-671

Strasburg DW (1969) Billfishes of the central Pacific Ocean. US Fish Wildl Serv Circ 311

Strasburg DW (1970) A report on the billfishes of the central Pacific Ocean. Bull Mar Sci 20:575-604

Takeuchi Y (2001) Is historically available hooks-per-basket information enough to standardize actual hooks-per-basket effects on CPUE? Preliminary simulation approach. Collect Vol Sci Pap ICCAT 53:356-364

Watson JW, Epperly SP, Shah AK, Foster DJ (2005) Fishing methods to reduce sea turtle mortality associated with pelagic longlines. Can J Fish Aquat Sci 62:965-981

Yang WS, Gong Y (1987) The vertical distribution of tunas and billfishes, and fishing efficiency between Korean regular and deep longlines in the Atlantic Ocean. Collect Vol Sci Pap ICCAT 26:184-187

Yokawa KY, Uozumi Y (2001) Analysis of operation pattern of Japanese longliners in the tropical Atlantic and their blue marlin catch. Collect Vol Sci Pap ICCAT 53:318-336

Yokawa K, Takeuchi Y, Okazaki M, Uozumi Y (2001) Standardizations of CPUE of blue marlin and white marlin caught by Japanese longliners in the Atlantic Ocean. Collect Vol Sci Pap ICCAT 53:345-355 
Appendix 1. Makaira nigricans. Details for setup, release, and pop-up/recovery from 51 PSATs deployed on Atlantic blue marlin. PTT: platform transmitter terminal

\begin{tabular}{|c|c|c|c|c|c|c|c|c|c|}
\hline No. & $\begin{array}{c}\text { PTT } \\
\text { ID }\end{array}$ & $\begin{array}{l}\text { Date } \\
\text { released }\end{array}$ & $\begin{array}{l}\text { Sampling } \\
\text { interval } \\
\text { (s) }\end{array}$ & $\begin{array}{l}\text { Estimated } \\
\text { weight } \\
(\mathrm{kg})\end{array}$ & $\begin{array}{c}\text { Days-at-liberty/ } \\
\text { days } \\
\text { programmed }\end{array}$ & $\begin{array}{l}\text { Displace- } \\
\text { ment } \\
(\mathrm{km})\end{array}$ & $\begin{array}{l}\text { Release } \\
\text { location }\end{array}$ & $\begin{array}{l}\text { Location } \\
\text { of first } \\
\text { transmission }\end{array}$ & $\begin{array}{c}\text { No. days } \\
\text { data } \\
\text { transmitted }\end{array}$ \\
\hline 1 & 22870 & 9 Jun 02 & 60 & 68 & $36 / 36$ & 924 & $28^{\circ} 43^{\prime} \mathrm{N}, 78^{\circ} 54^{\prime} \mathrm{W}$ & $36^{\circ} 16^{\prime} \mathrm{N}, 74^{\circ} 46^{\prime} \mathrm{W}$ & 36 \\
\hline 2 & 23548 & 11 Jun 02 & 60 & 147 & $29 / 41$ & 904 & $28^{\circ} 46^{\prime} \mathrm{N}, 78^{\circ} 47^{\prime} \mathrm{W}$ & $36^{\circ} 00^{\prime} \mathrm{N}, 74^{\circ} 22^{\prime} \mathrm{W}$ & 29 \\
\hline 3 & 22872 & 14 Jun 02 & 60 & 57 & $26 / 44$ & 653 & $23^{\circ} 56^{\prime} \mathrm{N}, 74^{\circ} 37^{\prime} \mathrm{W}$ & $25^{\circ} 00^{\prime} \mathrm{N}, 68^{\circ} 16^{\prime} \mathrm{W}$ & 26 \\
\hline 4 & 25999 & 14 Jun 02 & 60 & 57 & $44 / 45$ & 1386 & $23^{\circ} 56^{\prime} \mathrm{N}, 74^{\circ} 31^{\prime} \mathrm{W}$ & $17^{\circ} 24^{\prime} \mathrm{N}, 63^{\circ} 15^{\prime} \mathrm{W}$ & 44 \\
\hline 5 & 24793 & 17 Jun 02 & 60 & 50 & $5 / 41$ & 127 & $22^{\circ} 51^{\prime} \mathrm{N}, 74^{\circ} 23^{\prime} \mathrm{W}$ & $24^{\circ} 00^{\prime} \mathrm{N}, 74^{\circ} 24^{\prime} \mathrm{W}$ & 5 \\
\hline 6 & 23077 & 21 Jun 02 & 60 & 40 & $23 / 37$ & 143 & $23^{\circ} 47^{\prime} \mathrm{N}, 74^{\circ} 22^{\prime} \mathrm{W}$ & $22^{\circ} 30^{\prime} \mathrm{N}, 74^{\circ} 19^{\prime} \mathrm{W}$ & 23 \\
\hline 7 & 22873 & 28 Jun 02 & 60 & 57 & $22 / 43$ & 208 & $28^{\circ} 55^{\prime} \mathrm{N}, 74^{\circ} 24^{\prime} \mathrm{W}$ & $24^{\circ} 26^{\prime} \mathrm{N}, 75^{\circ} 36^{\prime} \mathrm{W}$ & 5 \\
\hline 8 & 25874 & 30 Jun 02 & 60 & 57 & $26 / 41$ & 282 & $22^{\circ} 48^{\prime} \mathrm{N}, 74^{\circ} 23^{\prime} \mathrm{W}$ & $20^{\circ} 15^{\prime} \mathrm{N}, 74^{\circ} 10^{\prime} \mathrm{W}$ & 2 \\
\hline 9 & 26000 & 1 Jul 02 & 60 & 57 & $27 / 40$ & 1230 & $21^{\circ} 56^{\prime} \mathrm{N}, 74^{\circ} 19^{\prime} \mathrm{W}$ & $32^{\circ} 19^{\prime} \mathrm{N}, 68^{\circ} 13^{\prime} \mathrm{W}$ & 7 \\
\hline 10 & 23520 & 2 Jul 02 & 60 & 102 & $25 / 39$ & 452 & $22^{\circ} 48^{\prime} \mathrm{N}, 74^{\circ} 21^{\prime} \mathrm{W}$ & $26^{\circ} 47^{\prime} \mathrm{N}, 73^{\circ} 24^{\prime} \mathrm{W}$ & 25 \\
\hline 11 & 26005 & $6 \mathrm{Jul} 02$ & 60 & 57 & $13 / 35$ & 135 & $22^{\circ} 49^{\prime} \mathrm{N}, 74^{\circ} 23^{\prime} \mathrm{W}$ & $22^{\circ} 42^{\prime} \mathrm{N}, 75^{\circ} 41^{\prime} \mathrm{W}$ & 9 \\
\hline 12 & 26001 & 8 Jul 02 & 60 & 159 & $26 / 33$ & 1468 & $22^{\circ} 47^{\prime} \mathrm{N}, 74^{\circ} 31^{\prime} \mathrm{W}$ & $35^{\circ} 31^{\prime} \mathrm{N}, 70^{\circ} 09^{\prime} \mathrm{W}$ & 26 \\
\hline 13 & 26935 & 12 Oct 02 & 60 & 57 & $39 / 39$ & 529 & $18^{\circ} 43^{\prime} \mathrm{N}, 74^{\circ} 22^{\prime} \mathrm{W}$ & $21^{\circ} 47^{\prime} \mathrm{N}, 60^{\circ} 55^{\prime} \mathrm{W}$ & 39 \\
\hline 14 & 27825 & 12 Oct 02 & 60 & 57 & $39 / 39$ & 1049 & $18^{\circ} 42^{\prime} \mathrm{N}, 64^{\circ} 49^{\prime} \mathrm{W}$ & $15^{\circ} 34^{\prime} \mathrm{N}, 74^{\circ} 07^{\prime} \mathrm{W}$ & $38^{\mathrm{b}}$ \\
\hline 15 & 23205 & 13 Oct 02 & 60 & 57 & $38 / 38$ & 2213 & $18^{\circ} 43^{\prime} \mathrm{N}, 74^{\circ} 22^{\prime} \mathrm{W}$ & $07^{\circ} 32^{\prime} \mathrm{N}, 47^{\circ} 54^{\prime} \mathrm{W}$ & 35 \\
\hline 16 & 39334 & 14 Oct 02 & 60 & 36 & $37 / 37$ & 423 & $18^{\circ} 51^{\prime} \mathrm{N}, 64^{\circ} 47^{\prime} \mathrm{W}$ & $22^{\circ} 26^{\prime} \mathrm{N}, 66^{\circ} 11^{\prime} \mathrm{W}$ & 16 \\
\hline 17 & 23520 & 23 Apr 03 & 60 & 60 & $40 / 40$ & 409 & $18^{\circ} 29^{\prime} \mathrm{N}, 68^{\circ} 23^{\prime} \mathrm{W}$ & $16^{\circ} 45^{\prime} \mathrm{N}, 65^{\circ} 00^{\prime} \mathrm{W}$ & 40 \\
\hline 18 & 41523 & 4 Jun 03 & 30 & 80 & $95 / 95$ & 407 & $24^{\circ} 06^{\prime} \mathrm{N}, 75^{\circ} 15^{\prime} \mathrm{W}$ & $24^{\circ} 33^{\prime} \mathrm{N}, 71^{\circ} 17^{\prime} \mathrm{W}$ & 92 \\
\hline 19 & 41524 & 4 Jun 03 & 30 & 68 & $82 / 95$ & 594 & $24^{\circ} 06^{\prime} \mathrm{N}, 75^{\circ} 17^{\prime} \mathrm{W}$ & $19^{\circ} 04^{\prime} \mathrm{N}, 73^{\circ} 33^{\prime} \mathrm{W}$ & $81^{\mathrm{b}}$ \\
\hline 20 & 41518 & 5 Jun 03 & 30 & 45 & $63 / 63$ & 840 & $24^{\circ} 03^{\prime} \mathrm{N}, 75^{\circ} 20^{\prime} \mathrm{W}$ & $31^{\circ} 12^{\prime} \mathrm{N}, 77^{\circ} 36^{\prime} \mathrm{W}$ & 63 \\
\hline 21 & 41520 & 5 Jun 03 & 30 & 82 & $63 / 63$ & 1530 & $24^{\circ} 06^{\prime} \mathrm{N}, 75^{\circ} 15^{\prime} \mathrm{W}$ & $36^{\circ} 52^{\prime} \mathrm{N}, 69^{\circ} 13^{\prime} \mathrm{W}$ & 63 \\
\hline 24 & 23388 & 7 Jun 03 & 30 & 55 & $60 / 60$ & 853 & $20^{\circ} 15^{\prime} \mathrm{N}, 72^{\circ} 28^{\prime} \mathrm{W}$ & $16^{\circ} 14^{\prime} \mathrm{N}, 66^{\circ} 17^{\prime} \mathrm{W}$ & 10 \\
\hline 22 & 41521 & 7 Jun 03 & 30 & 68 & $61 / 61$ & 367 & $24^{\circ} 06^{\prime} \mathrm{N}, 75^{\circ} 15^{\prime} \mathrm{W}$ & $22^{\circ} 15^{\prime} \mathrm{N}, 72^{\circ} 46^{\prime} \mathrm{W}$ & $44^{\mathrm{b}}$ \\
\hline 23 & 41525 & 7 Jun 03 & 30 & 102 & $41 / 121$ & 645 & $24^{\circ} 07^{\prime} \mathrm{N}, 75^{\circ} 16^{\prime} \mathrm{W}$ & $29^{\circ} 54^{\prime} \mathrm{N}, 75^{\circ} 56^{\prime} \mathrm{W}$ & 41 \\
\hline 25 & 41526 & 7 Jun 03 & 30 & 82 & $84 / 121$ & 1289 & $24^{\circ} 07^{\prime} \mathrm{N}, 75^{\circ} 18^{\prime} \mathrm{W}$ & $35^{\circ} 42^{\prime} \mathrm{N}, 73^{\circ} 49^{\prime} \mathrm{W}$ & 82 \\
\hline 26 & 23389 & 8 Jun 03 & 30 & 55 & $61 / 61$ & 892 & $20^{\circ} 15^{\prime} \mathrm{N}, 72^{\circ} 50^{\prime} \mathrm{W}$ & $16^{\circ} 02^{\prime} \mathrm{N}, 67^{\circ} 15^{\prime} \mathrm{W}$ & 61 \\
\hline 27 & 23397 & 9 Jun 03 & 30 & 50 & $38 / 93$ & 259 & $20^{\circ} 18^{\prime} \mathrm{N}, 72^{\circ} 37^{\prime} \mathrm{W}$ & $18^{\circ} 59^{\prime} \mathrm{N}, 72^{\circ} 51^{\prime} \mathrm{W}$ & 38 \\
\hline 28 & 41522 & 9 Jun 03 & 30 & 50 & $10 / 59$ & 159 & $24^{\circ} 05^{\prime} \mathrm{N}, 75^{\circ} 15^{\prime} \mathrm{W}$ & $25^{\circ} 05^{\prime} \mathrm{N}, 74^{\circ} 08^{\prime} \mathrm{W}$ & 10 \\
\hline 29 & 41528 & 10 Jun 03 & 30 & 52 & $69 / 69$ & 468 & $24^{\circ} 07^{\prime} \mathrm{N}, 75^{\circ} 17^{\prime} \mathrm{W}$ & $28^{\circ} 16^{\prime} \mathrm{N}, 74^{\circ} 17^{\prime} \mathrm{W}$ & $69^{\mathrm{b}}$ \\
\hline 30 & 41516 & 11 Jun 03 & 30 & 45 & $57 / 57$ & 401 & $24^{\circ} 03^{\prime} \mathrm{N}, 75^{\circ} 26^{\prime} \mathrm{W}$ & $27^{\circ} 15^{\prime} \mathrm{N}, 73^{\circ} 47^{\prime} \mathrm{W}$ & 56 \\
\hline 31 & 41538 & 16 Jun 03 & 30 & 136 & $47 / 75$ & 2092 & $21^{\circ} 59^{\prime} \mathrm{N}, 72^{\circ} 02^{\prime} \mathrm{W}$ & $14^{\circ} 17^{\prime} \mathrm{N}, 54^{\circ} 02^{\prime} \mathrm{W}$ & 47 \\
\hline 32 & 41534 & 17 Jun 03 & 30 & 193 & $46 / 67$ & 1014 & $22^{\circ} 00^{\prime} \mathrm{N}, 72^{\circ} 04^{\prime} \mathrm{W}$ & $19^{\circ} 08^{\prime} \mathrm{N}, 62^{\circ} 47^{\prime} \mathrm{W}$ & $46^{\mathrm{b}}$ \\
\hline 33 & 41539 & 18 Jun 03 & 30 & 45 & $74 / 74$ & 183 & $21^{\circ} 59^{\prime} \mathrm{N}, 72^{\circ} 04^{\prime} \mathrm{W}$ & $20^{\circ} 37^{\prime} \mathrm{N}, 71^{\circ} 19^{\prime} \mathrm{W}$ & 73 \\
\hline 34 & 41531 & 19 Jun 03 & 30 & 68 & $91 / 92$ & 4007 & $22^{\circ} 00^{\prime} \mathrm{N}, 72^{\circ} 04^{\prime} \mathrm{W}$ & $14^{\circ} 15^{\prime} \mathrm{N}, 35^{\circ} 13^{\prime} \mathrm{W}$ & 90 \\
\hline 35 & 41530 & 26 Jun 03 & 30 & 55 & $7 / 63$ & 182 & $22^{\circ} 51^{\prime} \mathrm{N}, 74^{\circ} 24^{\prime} \mathrm{W}$ & $24^{\circ} 30^{\prime} \mathrm{N}, 74^{\circ} 16^{\prime} \mathrm{W}$ & 7 \\
\hline 36 & 41527 & 14 Jul 03 & 30 & 45 & $41 / 96$ & 672 & $32^{\circ} 03^{\prime} \mathrm{N}, 65^{\circ} 01^{\prime} \mathrm{W}$ & $35^{\circ} 09^{\prime} \mathrm{N}, 71^{\circ} 07^{\prime} \mathrm{W}$ & 41 \\
\hline 37 & 41537 & 24 Jul 03 & 30 & 160 & $45 / 45$ & 870 & $32^{\circ} 07^{\prime} \mathrm{N}, 64^{\circ} 60^{\prime} \mathrm{W}$ & $35^{\circ} 26^{\prime} \mathrm{N}, 56^{\circ} 26^{\prime} \mathrm{W}$ & 45 \\
\hline 38 & 41535 & 2 Sep 03 & 30 & 227 & $28 / 90$ & 574 & $18^{\circ} 34^{\prime} \mathrm{N}, 66^{\circ} 13^{\prime} \mathrm{W}$ & $14^{\circ} 35^{\prime} \mathrm{N}, 64^{\circ} 18^{\prime} \mathrm{W}$ & 28 \\
\hline 41 & 41540 & 3 Sep 03 & 30 & 57 & $7 / 94$ & 109 & $18^{\circ} 34^{\prime} \mathrm{N}, 66^{\circ} 13^{\prime} \mathrm{W}$ & $19^{\circ} 04^{\prime} \mathrm{N}, 65^{\circ} 22^{\prime} \mathrm{W}$ & 7 \\
\hline 39 & 42723 & 3 Sep 03 & 30 & 68 & $124 / 124$ & 2639 & $18^{\circ} 32^{\prime} \mathrm{N}, 66^{\circ} 11^{\prime} \mathrm{W}$ & $03^{\circ} 25^{\prime} \mathrm{N}, 48^{\circ} 51^{\prime} \mathrm{W}$ & 93 \\
\hline 40 & 42724 & 3 Sep 03 & 30 & 52 & 93/93 & 298 & $18^{\circ} 32^{\prime} \mathrm{N}, 66^{\circ} 11^{\prime} \mathrm{W}$ & $18^{\circ} 38^{\prime} \mathrm{N}, 63^{\circ} 19^{\prime} \mathrm{W}$ & $82^{\mathrm{b}}$ \\
\hline 42 & 49774 & 5 May 04 & 30 & 113 & $47 / 62$ & 1361 & $16^{\circ} 55^{\prime} \mathrm{N}, 25^{\circ} 20^{\prime} \mathrm{W}$ & $28^{\circ} 24^{\prime} \mathrm{N}, 30^{\circ} 57^{\prime} \mathrm{W}$ & 46 \\
\hline 43 & 49773 & 9 May 04 & 30 & 82 & $21 / 30$ & 283 & $16^{\circ} 59^{\prime} \mathrm{N}, 25^{\circ} 21^{\prime} \mathrm{W}$ & $14^{\circ} 26^{\prime} \mathrm{N}, 25^{\circ} 34^{\prime} \mathrm{W}$ & 18 \\
\hline 44 & 49777 & 10 May 04 & 30 & 95 & $15 / 45$ & 730 & $16^{\circ} 57^{\prime} \mathrm{N}, 25^{\circ} 23^{\prime} \mathrm{W}$ & $13^{\circ} 27^{\prime} \mathrm{N}, 30^{\circ} 40^{\prime} \mathrm{W}$ & 15 \\
\hline 46 & 49775 & 12 May 04 & 30 & 145 & $70 / 90$ & 748 & $16^{\circ} 45^{\prime} \mathrm{N}, 25^{\circ} 06^{\prime} \mathrm{W}$ & $17^{\circ} 25^{\prime} \mathrm{N}, 18^{\circ} 16^{\prime} \mathrm{W}$ & 54 \\
\hline 45 & 49778 & 12 May 04 & 30 & 181 & $56 / 56$ & 303 & $16^{\circ} 45^{\prime} \mathrm{N}, 25^{\circ} 06^{\prime} \mathrm{W}$ & $17^{\circ} 55^{\prime} \mathrm{N}, 22^{\circ} 30^{\prime} \mathrm{W}$ & 28 \\
\hline 47 & 53733 & 14 Oct 04 & 30 & 363 & $4 / 100$ & 35 & $07^{\circ} 54^{\prime} \mathrm{S}, 14^{\circ} 26^{\prime} \mathrm{W}$ & $08^{\circ} 06^{\prime} \mathrm{S}, 14^{\circ} 34^{\prime} \mathrm{W}$ & 4 \\
\hline 48 & 53244 & 16 Oct 04 & 30 & 45 & $44 / 44$ & 1663 & $07^{\circ} 51^{\prime} \mathrm{S}, 14^{\circ} 24^{\prime} \mathrm{W}$ & $07^{\circ} 24^{\prime} \mathrm{N}, 16^{\circ} 43^{\prime} \mathrm{W}$ & 44 \\
\hline 49 & 53245 & 19 Oct 04 & 30 & 125 & $36 / 55$ & 728 & $07^{\circ} 54^{\prime} \mathrm{S}, 14^{\circ} 14^{\prime} \mathrm{W}$ & $03^{\circ} 32^{\prime} \mathrm{S}, 09^{\circ} 25^{\prime} \mathrm{W}$ & 36 \\
\hline 50 & 53736 & 7 Nov 04 & 30 & 90 & $90 / 90$ & 2535 & $07^{\circ} 49^{\prime} \mathrm{S}, 14^{\circ} 20^{\prime} \mathrm{W}$ & $26^{\circ} 47^{\prime} \mathrm{S}, 26^{\circ} 06^{\prime} \mathrm{W}$ & 15 \\
\hline 51 & 53734 & 17 Nov 04 & 30 & 205 & $38 / 89$ & 1356 & $07^{\circ} 49^{\prime} \mathrm{S}, 14^{\circ} 20^{\prime} \mathrm{W}$ & $03^{\circ} 32^{\prime} \mathrm{N}, 10^{\circ} 39^{\prime} \mathrm{W}$ & 38 \\
\hline
\end{tabular}

Editorial responsibility: Jon Hare, Narragansett, Rhode Island, USA
Submitted: June 15, 2007; Accepted: April 2, 2008

Proofs received from author(s): July 31, 2008 